\title{
Improved Speaking Ability Through the "Reality Show" at the Academia Student Center
}

\author{
Metro Jaya ${ }^{1}$, Emzir $^{2}$, Zainal Rafli ${ }^{3}$ \\ \{metrojaya_pb09s3@mahasiswa.unj.ac.id ${ }^{1}$, emzir.unj@unj.ac.id², zainal.rafli@unj.ac.id ${ }^{3}$ \} \\ Jurusan Pendidikan Bahasa,Universitas Negeri Jakarta, Indonesia ${ }^{1,2,3}$
}

\begin{abstract}
In the issues of global area with revolution 4.0 is signed by Critical Thinking and Problem Solving, Communicative, Creativity and Collaborative. Teachers must implement in the teaching and learning in the class. Educators in Indonesian language subjects, especially in regions and corners of the country (remote area), still cannot and try to do much, have not tried experimenting with various possible tips, techniques, methods, strategies and learning models. Learning Indonesian especially in the aspect of speaking skills prioritizes providing information about speaking techniques and strategies and very little time is spent on practicing speaking skills. Learning also lacks markers of evaluation that can support speaking skills. The contextual approach is believed to be able to encourage learner motivation to move in learning. The strategy of CTL was used is "Reality Show Academia Student Center" with learning steps named in terms "I Competence Because of Usual" will give a real psychological impact and close to the learners themselves. The steps offered in the learning that adapted the reality show were summarized in the wise sentence, "AKU BISA KARENA BIASA" (I competence becouse of usual). These steps can be explained concretely as follows, they are :1) Aku $=$ Atur Kekuatan (Arrange the strength), 2) BISA $\{$ Can $\}=$ BIsikkan seSAma (Communicate to others), 3) KARENA = KARya sempurNa (Works are perfect ), 4) BIASA $($ Usual $)=$ Bicarakan intisarinya $($ Talk about the essence $)$.
\end{abstract}

Keyword. Contextual Teaching and Learning, speaking ability.

\section{Introduction}

The demands of the global era so that teachers are always ready to compete locally, nationally, regionally and even internationally. While the complexity of the problem of civilization has disguised the space and elements of education. On the other hand, life skills and skills are very much determined by education. Education is central to the development of life with its culture. Education embodies communication with its technology as the key to the establishment of culture and civilization.

Language is the realm or domain of life and also a place for human culture and civilization. Language is also a complex behavior, involving internal and external elements of individual language users. Language learning should be an organized activity that can be accounted for, didactic, methodical and even scientific practice. The weak of language development will slow down the cultural development of every society. The weak mastery of language greatly influences the slow development of individual cultures or the people concerned. Language as a means of communication develops culture as the most important element in mastering civilization. 
The culture and lifestyle of bourgeoisie and hedonism are very thick and inherent with young people or students today. What is very possible is to make it a means of cultural transfer and learning in the sense of using it from a positive side to optimize education and learning. Education with learning must be keen to see opportunities and aspects of this culture to be optimized to become a means of developing the process of education and learning.

Indonesian language education and learning in schools cannot be said to be able to have an adequate impact on students' language mastery. This is evident from the number of students who have not been able to convey their ideas clearly, logically and systematically in academic assignments and in everyday life.

A C. Alwasilah (2011) revealed that the current learning conditions of Indonesian Language have not had a positive impact in developing the language skills of their students. Language teachers become one man shows. Other subject teachers are also mostly ignorant about learning and using Indonesian.

Teachers or educators on Indonesian language subjects, especially in regions and corners of the country (remote area), still cannot and try to do much, have not tried experimenting with various possible tips, techniques, methods, strategies and learning models. Learning Indonesian especially in the aspect of speaking skills prioritizes providing information about speaking techniques and strategies and very little time is spent on practicing speaking skills. Learning also lacks markers of evaluation that can support speaking skills.

\section{Ease To Use}

The contextual approach is believed to be able to encourage learner motivation to move (learn) in learning. According to Elaine BJ, Ph. D (2011) eight components of CTL will be able to be empowered, namely: Making Meaningful Linkages, Independent Learning, Doing Meaningful Work, Working Together, Creative and Critical Thinking, Helping Individuals to Grow and Develop, Achieving High Standards, and Using Authentic Assessment, which is applied in the Seven CTL Pillars, namely Constructivism, Inquiry, Questioning, Learning Community, Modeling, Reflection, and Authentic Assessment in Nurhadi (2002).

Problems Learning of Indonesian:

1. Learning is a 'text book' or fixated on textbooks or textbooks.

2. Learning runs simply or can be said to be less conceptual and unplanned. RPP (Lesson Plan) is more of a formality and becomes the occupant of the teacher's drawer.

3. Learning languages, especially speaking skills seem monotonous. Language theory dominates teaching material rather than language practice.

4. Language subject teachers are more skilled at becoming 'critics' of the students' language rather than being model or examples of language for their students.

Most teachers prefer learning models that are oriented towards literacy skills with lectures. Less speaking skills get an adequate portion.

So, overall, the difficulties and development of the speech of students can be seen in several parts of the language, namely: Mastery of Discussion Topics, Diction, Grammar, Language Attitude, Pronunciation, and flexibility. These points will be a reference for evaluating students' speaking skills. 


\section{Methods}

This is the action research can be used effectively to bridge the gap between theory and practice, to improve educational practice, to empower teacher, to provide professional growth opportunities for teachers, to identify educational problems, to develop and test solutions, and to expand the knowledge base of preservice teachers.

Learning must be packaged in a series of activities that really can bring students dissolved in experience and interpret it contextually and measurably. Then the strategy "Reality Show Academia Student Center" with learning steps named in terms "I Competence Because of usual" will give a real psychological impact and close to the learners themselves.

The concrete steps of the Reality Show adopted one of the private TV broadcasts titled "Mamamia Seleb Konser" (Indosiar TV) many times ago. The teaching materials for this reality show model can actually be used for all Indonesian material, but on this occasion it was devoted to material expressing criticism and praise for the artwork (Poetry and Short Story Literature) only. Poetry takes precedence in poetry making and poetry reading, including poetry musicalization. Also for short stories, create short stories and reading short stories.

\section{Results}

The steps offered in the learning that adapted the reality show were summarized in the wise sentence, "AKU BISA KARENA BIASA" (I competence becouse of usual). These steps can be explained concretely as follows.

1. $\mathrm{Aku}=$ Atur Kekuatan ( Arrange the strength) $\backslash$

Atur Kekuatan (Arrange Strength) as the first step the teacher introduces how to learn to speak and the things that will be discussed. This first step consists of several reference activities:

a. Discuss the material to be discussed.

b. Sharing work groups. Division of groups according to learning need, available time and ability of students to report the results of their acquisition or their learning. Each group can consist of 4-5 students. Classes are divided into seven groups. The last, they will take turns being the actor, commentator and promoter.

c. Determine the part of learning material from each group.

d. Introduce things that will be prioritized or staged (shown).

e. The main points in the aspect of speaking, (such as how to praise, how to criticize, how to give advice and attitudes that need to be considered and improved).

f. Also discuss the aspects of speech that will be studied, namely: Mastery of Discussion Topics, Diction, Grammar, Language Attitude, and Pronunciation.

g. Things that are considered necessary by students to increase their participation in learning

2. BISA $\{$ Can $\}=$ BIsikkan seSAma /communicate to others

This is the second phase, where students in groups discuss understanding the learning material, deepen and broaden their knowledge about matters relating to teaching material as well as tips or ways they agree to their delivery or appearance. This phase becomes the determination phase. Each group shares work in several tasks (with teacher guidance). It is sought so that each person in the group has a role, 
starting from as a Host (moderator), Sang Bintang or performer (displaying the work), Secretary, Group Chair person, and Member who also serves as a Promoter (expressing the good appearance of Sang Bintang presentation). Essentially, each group member must have a role in conveying and promoting their group work.

Activities in this second phase include:

a. Learners explore the material and / or the work they will perform. Each group makes and will present their work.

b. Each student shares assignments. Begin by trying or perform each participant in the group. Because, it could be when they perform, the group wants all to be performed (the reason they are fair). Depending on group and class agreement and the teacher with the time available.

c. Help each other to prepare the conversation material for both of the host, the star (introduction), or even the promotional sentence they will perform.

d. Prepare supporting facilities and infrastructure that students consider necessary.

e. The teacher pays attention and gives reinforcement and still encourages students to be able to do and believe they will.

The students has been motivated in working together, that is correlated with Kitjaroonchai "Instrumental motivation has significantly correlated with students learning".

\section{KARENA $=$ KARya sempur $\mathrm{Na}$ (Works are perfect)}

In this third phase students in groups present their performance and or discussion about the material they get. Each group determines one star (the best) from them to present their performance. Like a show, their performance in front of the classmates will be the center of attention and material to be commented on by other groups appointed.

In this phase, the ability to speak to process and express ideas and thoughts becomes very important. All group members are obliged to pay attention and give their care and empathy to the Star. Here we need speaking skills that express the good sides of the performance of Sang Bintang.

This step will consist of:

a. Determination of group performance turn, also determination of other groups who will act as promoters, and other groups as commentators. To make it easier, if group one (1) performs then group two (2) as promoter, and group seven (7) as commentators. If group two (2) performs then group three (3) as promoter and group one (1) as commentator. Etc.

b. Group performance is begun with the introduction of group members and their roles, by Host.

c. The host has a role in regulating the class activities, starting from the performance of the group, setting up promotional requests in the promotion group, commenting on the group acting as commentators. Do not forget to ask for a reflection of their performance from the map teacher as (considered) a guest judge.

d. After introducing group personnel, the host invited the Bintang Group to perform their work (the result of a group agreement).

e. After the performance, the host invited his group members to promote the performance of the star. Praising skills with sentences that are good and polite and not excessive. Including the host must be able to give praise.

f. Followed by host requests to groups acting as promoters to supplement, add or promote their group's performance. The promoter group and commentators are provided with working papers to help them prepare their promotions and comments. 
g. After that, the host asks for criticism and suggestions to the commentator group for their comments.

h. The secretary takes notes and can base on feedback if necessary.

i. The host asks for a reflection from the Guest Judge. The teacher attends to giving compliments with tangible evidence and must be able to arouse the enthusiasm of students to always want and will to be active and creative.

j. Guest Judges (teachers) will ask for concurrent evaluations of other group students who have not yet played a role (other than presenters, promoters, and commentators) to express their assessment in the paper vote of the lock they have obtained.

$\mathrm{k}$. The host closes the performance and continues to the next group. In a way that is more than is the same, until all groups perform and got the role of promoters and commentators.

4. BIASA $($ Usual $)=$ Bicarakan intisarinya (Talk about the essence).

Each group will get a reflection and input from expert witnesses (teachers) as mediators and embrace all activities and opinions of students wisely to strengthen the learning of their students. It is done well after each group performs, also at the end of a one-time meeting faceto-face and to end all series of learning after all groups have finished performing. The teacher as a learning facilitator must have brief and light notes about the performance of his students. The results of student work documented through working papers that have been provided previously are authentic references as a basis for reflection on learning.

Cooperation naturally helps learners suppress or reduce feelings of stress by situations and conditions and more to use their mental energy to learn. Meier (2005) mentions that creating human synergy that allows various insights, ideas and information to flow freely. Contextual learning helps student associate academic lessons with their real-life context. Students are guided to associate academic content with context in real life situations. Learners find meaning.

Emotional involvement of teachers and truly also becomes important for the quality of this learning. The teacher's expertise in sorting words and comments and promotional sentences (giving advice or criticism) is good and directing the course of class discussions (learning) effectively and efficiently.The aspects that will be used as a reference assessment to see the learner's abilities in conducting this research are as follows. Mastery of Discussion Topics, Diction, Grammar, Attitudes, Pronunciation, and Dexterity.

\section{Discussion}

AKU BISA KARENA BIASA (I competence becouse of usual)

Accustoms students to be responsible for their roles. The duty and obligation of the teacher to always monitor all the movements and behavior of the students so that they do not dissolve in the 'bullshit talk' because they are too out of control or do not get attention. The habits and character of the teacher in guiding are the main model to train students' character in shaping their character. AKU BISA KARENA BIASA (I competence becouse of usual) makes it easy for teachers to manage learning if the learning is planned and properly controlled.

1. Mastery of Discussion Topics

Giving time and opportunity to students to work in groups makes it easier for them to get information input among others. 
2. Diction

The amount of information they receive, including when sharing promotions and comments that are done repeatedly, provides opportunities for students to get a lot of vocabulary and a variety of delivery methods.

3. Grammar

Generally habituation and repetition of information delivery is a good time for students to learn grammar.

4. Attitude

The culture of "Be able to be usual" is a branding for learning a language that is good enough to be developed. Proverb: Language Shows Nation to be very suitable to encourage polite language behavior in the learning process.

5. Fluency

A habit that is sustainable and in good supervision will have an impact on learning for each students.

6. Flexibility

The results, ideas and critical thinking will be built easily and measurably.

The class average value that students get (with an average range between $2.00-3.50$ ) reaches 3.07. Compared to the maximum score that they might get, which is 4.00 , then the number 3.07 already means reaching a success rate of $76.64 \%$. Referring to the complete expectation limit of class speaking learning is $75 \%$, the percentage value obtained can be said to be good or exceed the expected grade completeness target.

The value of the acquisition of practical classes for each aspect of the assessment can also be said to be good. Classically the percentage of students' mastery of the Mastery aspects of the Discussion Topics reached $67.0 \%$. Word choice: $72.3 \%$. Grammar: $84.8 \%$. Attitude: $80.4 \%$. Pronunciation: $83.0 \%$. Flexibility: $72.3 \%$. The author gets, if the implementation of learning with the reality show model is carried out regularly and repeatedly, it will be able to further improve the level of mastery of students on all aspects of speech desired. It takes repetition to get the perfection of skills. That's right. Habitual actions will defeat incompetence.

That result is suitable with Bliuc, Ellis, Goodyear and Hendres at their research , "The supportive learning environment have been linked to the high engagement in learning performance and independent learning that determined the academic success and students' satisfaction.

For the value of character development, the students are in the good and even very good category. The value of participants from the judges of Vote Lock is between 77 to 87 which can be categorized as good and very good (> 84).

\section{Conclusion}

The success of learning using a contextual approach by presenting a Reality Show style learning strategy with the name Akademia Student Center is very suitable to relate the current culture with the needs of students. The learning steps with AKU BISA KARENA BIASA is an effort to optimize the involvement of students in learning. Pillars of Contextual Teaching and Learning can be implemented in this reality show-style learning. So it is strongly recommended that this learning model can be developed in other topics and other subjects. 


\section{References}

[1] Alwasilah, A. Chaedar. (2010). Pokoknya Action Research. Bandung: PT Kiblat Buku Utama.

[2] Bliuc A.M, Ellis. R.A, Goodyear P. \& Hendres, D. M. (2011). Understanding student learning in context: relationships between university students' social identity, approaches to learning, and academic performance.. European Journal of Psychology of Education

[3] Garnet, Linda D \& Kimmel, Douglas C (2003). Psychological Perspectives On Lesbian, Gay, and Bisexual Experiences, New York: Colombia University Press.

[4] Johnson, Elaine B. (2002). CTL (Contextual Teaching \& Learning). (penerj: Ibnu Setiawan). Bandung: Mizan Media Utama.

[5] Joyce, Bruce. dkk. (2009). Models of Teaching. (edisi kedelapan) (penerj: Ahmad dan Ateilla). Yogyakarta: Pustaka Pelajar.

[6] Kitjaroonchai, N. \& Kitjaroonchai, T. (2012). Motivation Toward English Language Learning of Thai Students Majoring in English at Asia-Pacific International University.

[7] Meier, Dave. (2005). The Accelerated Learning. Handbook. (penerj: Rahmani Astuti). Bandung: Kaifa.

[8] Nurhadi. (2002). Pendekatan Kontekstual (Contextual Teaching And Learning). Malang: Universitas Negeri Malang.

[9] Paul Eggen \& Don Kauchak. (2012) Strategi dan Model Pembelajarn: Mengajarkan Konten dan Keterampilan Berpikir (edisi keenam). Jakarta: PT Indeks.

[10] Richards, Jack C \& Rodgers, Theodore S. (1986) Approaches and Language Teaching: A Description and Analysis. USA: Cambridge University Press.

[11] Stringer, Ernest T. (2007) Action Research.Third Edition. USA: SAGE Publications. 